\title{
Missio hominum as the compassionate response to socio-economic and vaccine challenges during COVID-19 in South Africa
}

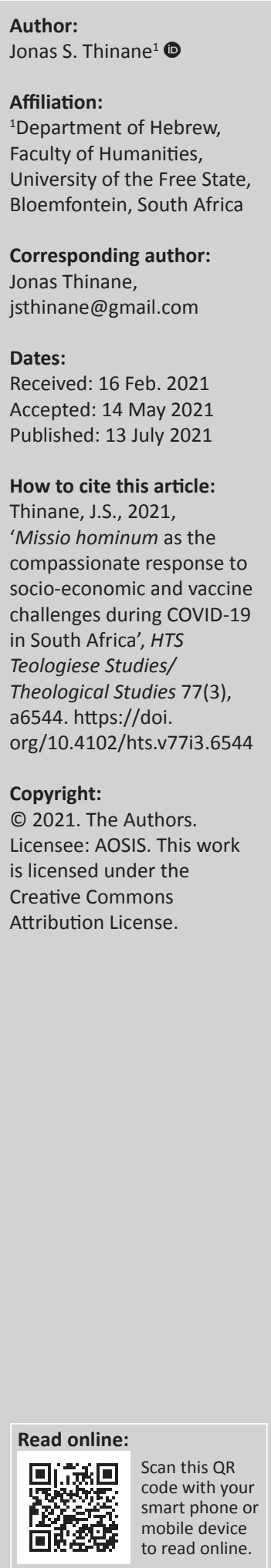

It is likely that the storm of coronavirus disease 2019 (COVID-19) in South Africa will calm only when the country attains herd immunity. In South Africa, the COVID-19 vaccine roll-out plan will first prioritise key frontline forces, the elderly and those with comorbidities. Although there is some new academic insight on COVID-19 within the context of churches, not much has been written on the role that churches can play in partnership with government towards procuring vaccines for the poor people of South Africa. The contribution towards vaccine procurement by churches is juxtaposed with the proclamation of the year of the Lord's favour in Luke 4:18-19 and the feeding of 5000 men (excluding women and children) in Matthew 14:13-21, Mark 6:30-44, John 6:1-14 and Luke 9:10-17. This is done against an environment where corruption in the procurement of personal protective equipment, unjust food parcel distribution and subverted relief packages occurred during the hard lockdown of 2020. This article makes use of both missio Dei and missio hominum as its missiological theory in conformity with calls for public health restoration during and after COVID-19. It employs a literature review to support missio Dei and missio hominum as compassion and fundraising for the poor in the face of COVID-19, as exemplified by Paul in 1 Corinthians 16:1-4 and Jesus in Mark 6:8 and Luke 8:1-3.

Contribution: In order to preserve lives that would otherwise be lost whilst waiting for the COVID-19 vaccine, this article entreats all churches of South Africa to launch a nationwide church fundraising effort towards procuring COVID-19 vaccines for the poor following the example of the Solidarity Fund, which was established by President Cyril Ramaphosa as one of the early interventions to cushion the impact of COVID-19.

Keywords: COVID-19; missio hominum; vaccine; fundraising; personal protective equipment.

\section{Introduction}

According to Khan and McIntosh (2005:223) the history of coronavirus disease 2019 (COVID-19) can be dated back to 1965. Since that period, other types and groups of coronaviruses have been discovered. One such was severe acute respiratory syndrome (SARS), emerging in 2002-2003. This new infection became an outbreak; it was reported in 29 North American and Caribbean countries, infecting about 8098 people, and 774 fatalities were recorded (Khan and McIntosh 2005:224). In December 2019, another new coronavirus emerged, called SARS-CoV-2, which subsequently caused the COVID-19 outbreak, first detected in Wuhan, China. Since then, COVID-19 has spread into multiple countries, leading the World Health Organization (WHO) to declare it a global pandemic. In South Africa alone, at the time of writing, COVID-19 had infected more than 1.5 million people and claimed 46180 lives. This article comes at a time when the second wave of the COVID-19 pandemic in South Africa is at its most devastating point. In his speech of 11 January 2021, President Cyril Ramaphosa indicated that the number of new infections, hospital admissions and deaths was much higher than it had been in March 2020 when the first cases of COVID-19 were recorded (Ramaphosa 2021). The South African government is optimistic that a possible way to stall the rapid spread of this virus and restore public health is by protecting a large part of its citizens, at least $67 \%$ (40 million + ), to reach herd immunity against COVID-19. The early arrival and availability of vaccines in South Africa will mean that the COVID-19 nightmare is about to end; South Africa has been one of the African countries with high and continually increasing numbers of COVID-19 cases (Kgatle 2020:5). The plan is that once South Africa receives COVID-19 vaccine doses, it will first cover 10\% of the total population. Apart from ending the pandemic nightmare, the arrival of the COVID-19 vaccine will come as a relief and 
give new hope to South African churches, which have had to lock their doors as the regulations prevented any physical contact, in particular during the Risk Adjusted Strategy Alert Levels 5-4.

In a context where the whole nation finds itself in a fierce war against the COVID-19 pandemic, with a costly massive rollout of vaccine believed to be one of the only effective methods to defeat the virus, it is important to have academic scholarship contributions in order to identify and determine the role that faith communities and churches can play to assist the restoration of public health.

Whilst the South African government intends to vaccinate the frontline workers first, this article calls on South African churches to demonstrate compassion by setting up a nationwide church fundraising effort for the separate procurement of vaccines and developing a vaccination plan that will prioritise the 'backline forces' (the poor and marginalised). The provision of vaccines by churches is juxtaposed with the feeding of 5000 men (not counting women and children) as indicated in Matthew 14:13-21, Mark 6:30-44, John 6:1-14 and Luke 9:10-17. This is done in accordance with the theory of missio Dei as understood by multiple scholars, such as Bosch (1991), Arthur (2013), Flett (2014), Van Aarde (2017), Soares, Lotter and van der Merwe (2017) and many others in the field of theology, and missio hominum as advocated by theological scholars such as Verkuyl (1981), Smith (2002) and Knoetze (2017). These two theories are interrelated as simultaneously God centred and human focused. The correspondence of missio Dei and missio hominum demonstrates the inseparableness of God's purpose for the church and his general purpose for humanity or the world (consisting of both believers and non-believers), which indirectly suggests the reflection of Jesus Christ being fully God and fully human. This article will suggest (missio hominum being the subfunction or subset of missio Dei) compassion and fundraising towards the procurement of vaccines for the poor in the face of COVID-19 as exemplified by Paul in 1 Corinthians 16:1-4 and Jesus in Mark 6:8 and Luke 8:1-3. This is set in an environment where corruption in the procurement of personal protective equipment (PPE), unjust food parcel distribution and subverted relief packages occurred during the hard lockdown of 2020. The following section provides a literature review on the theory of missio hominum as it exists within the broader phenomenon of missio Dei, before an analysis of the socio-economic challenges in the context of the pandemic

\section{Missiology as an interdisciplinary discipline}

This article will draw its knowledge from the field of missiology whilst calling for the restoration of public health. This approach coincides with Bosch's argument that mission is a multifaceted ministry as it relates to justice, service, reconciliation, peace, church planting, contextualisation, (societal) healing and much more (Bosch 1991:512). Kgatle could not have been more accurate in pointing out that a distinct feature of missiology is its capacity to blend approaches from different fields and incorporate them into one theological plan. He further concludes that 'missiology is therefore by its very nature interdisciplinary' (Kgatle 2018:2).

More than ever before, the church of Christ in the whole world is challenged to be more responsive and reactive in the fight against COVID-19 by working with the government in the work of restoring public health. As suggested by Corrie (2016), the church cannot go on doing mission as it has always done it (post- and pre-COVID-19). More than ever before the church will need to be more responsive and engage meaningfully and contextually with the new realities that have been engendered by the COVID-19 pandemic. This article will show the role that the churches of South Africa in particular are to play in preserving, protecting and improving the health of the entire society. The interdisciplinarity of this article begins at the juncture where the church is called to cross-function its role by being concerned with the task of preserving lives and restoring public health. Refering to Verkuyl (1981:19), Knoetze (2017:2) correctly pointed out that missio hominum is about non-church work by people working for the good of their society, thus taking part in the missio Dei unintentionally or intentionally.

\section{Missio Dei}

The Latin Christian theological term missio Dei can be translated as the 'mission of God' or 'God's mission'. This term articulates the mission of God as inherently using his people in that mission as instruments. In simple language, missio Dei is about the plan of God as executed by his people (Van Aarde 2017:284). The concept of missio Dei derives its theological mandate from the Great Commission, as articulated in Matthew 28 when Jesus said to his disciples:

All authority in heaven and on earth has been given to me. Go therefore and make disciples of all nations, baptizing them in the name of the Father and of the Son and of the Holy Spirit, and teaching them to obey everything that I have commanded you. (vv. 18-20)

By calling on his immediate disciples (apostles), essentially God calls the Church, through which the whole human fabric is called into mission of God.

Arthur (2013) agrees with Bosch (1991) that the history of the term missio Dei can be traced as far back as to Saint Augustine, who described God's work of restoration with the participation of the church (Arthur 2013:1-8; Bosch 1991:390). Furthermore, Saint Thomas Aquinas described God's activity as the father sending the son and the son sending the spirit. This can be further traced back to 1932, when Karl Barth introduced the idea of church mission (missio ecclesiae). This was followed by the work of Karl Hartenstein in 1934, who related missio Dei to Karl Barth's teachings, distinguished it from missio ecclesiae (Soares et al. 2017:1-7) and fleshed it out in detail after the 1952 meeting of the International Missionary Council at Willingen in Germany. 
Flett (2014) speaks of missio Dei as a plan in which God makes use of human beings to become witnesses of his acts, through which God himself crosses the gap between humanity and himself (Fleet 2014:73). The Triune God initiates the mission from the Old Testament through the sacrifice of his begotten Son in the New Testament; he remains actively involved to guarantee its success. He does all this, being compelled by his relational nature to invite humanity to participate in that mission with him (Arthur 2009:3). God invites human beings, in particular believers, to participate in his mission; that should not suggest that he is incapable to succeed unaided, but instead through his relational and gracious nature he invites human participation because in the process they will be saved. Thus, missio Dei is centred on God as the instigator and user of human beings (in particular the Christian community) as subjects and participants in his mission.

\section{Missio hominum}

The Latin term missio can broadly be translated to mean 'mission', and the term hominum can be translated to mean 'human being'. In the same fashion that missio Dei points to the mission of God, missio hominum is about the mission of humans (which includes both believers and nonbelievers alike). Knoetze (2017) is spot on in his suggestion that missio hominum refers to non-church work by people working together for the good of society in its entirety. Whilst this article seeks to apply the idea and principles of missio hominum to Christians, it does so without excluding the general public. Thus, the term missio hominum will be used to refer indiscriminately to both believers (in particular Christians) and non-believers knowingly or unknowingly taking part in the missio Dei (Knoetze 2017:2).

According to Bosch (1991, 2011), Christian mission has to have some crossing of barriers - whether they be economic, linguistic, religious or cultural- and through such crossing there be some communication of the message of Christ. The call for South African churches to identify with and demonstrate compassion to the plight of the poor in the context of the COVID-19 pandemic seems to be in line with Smith's understanding of missio hominum. He (2002) wrote:

[M] issio Hominum means believers going out into the world to be involved in the affairs of people in their context, identifying with them and demonstrating to them God's concern and love for the people. (p. 18)

The highlight here is that whilst missio Dei is about God sending his son to the world, missio hominum is about human beings (Christians and non-believers alike) either intentionally or unintentionally working towards the good of society or living out the purpose that the Son of God was sent to complete on earth. Further, Smith (2002) wrote:

[I] sincerely believe that God is calling people to all places in the world where people are in need, be it because of poverty, oppression, ignorance, lack of education, medical services or whatever. (p. 19)
This places the restoration of public health during and after COVID-19 squarely in the hands of churches in partnership with the South African government. He further argues that the time has arrived for all Christians to be responsible for the world to be aligned with what God intended through the incarnation of Jesus of Nazareth (Smith 2002:19).

Missiologically, one would not be too far from accuracy in describing missio hominum as the transition that takes place amidst the mission of God (missio Dei), represented in the acts of believers and non-believers or those who follow the example of Jesus of Nazareth (Christians, in this case). The resurrection of Jesus from the dead brought the age of the church, when his disciples became fully inspired and authorised to carry on the mission of Jesus in the community. Thus, the resurrection was an event when Christ was transferring authority to the church in order for it to work as his agent.

Missio hominum is consistent with the views of Verster (1997), who defined mission as 'the total task which God sets the church for the salvation of the world' (Verster 1997:251). According to Bosch (1991:512), mission has multiple aspects in the form of witness, justice, service, reconciliation, peace, fellowship, healing, contextualisation and much more. Consistent with this assertion, Verster (1997:253) wrote: ' $[t]$ he task of the church therefore covers a very broad spectrum, and the church is expected to be relevant for all issues'. Whilst the church on the one hand is the bearer of the good news about God and his kingdom, on the other hand, the church is duty bound to be a true illustration of God's involvement in the world.

Therefore, in understanding missio hominum, Christians will surely agree with the assertion that they are each called to participate in the redemptive ministry of Jesus Christ on earth. That as true disciples of Jesus Christ they are fully equipped for a ministry of love, hope, reconciliation and healing to the broken and traumatised world and ultimately reconcile human community with God. In his excellent article, Knoetze (2017) asked an important question, which reflects on and touches the foundation of this article. He asks: ' $[w]$ hat does it mean to be obedient to the mission calling in a broken and traumatized world at a specific time?' (Knoetze 2017:1). In its design, this question points to both societal brokenness and trauma as the predicate or premise for mission calling.

Missio hominum simply means that Christians in particular cannot continue to focus on missio Dei whilst in the process abandoning their inherent responsibility to heal and change the world for the better. However, it is important at this point to caution that this does not suggest that missio hominum can be separated from, supersede or replace missio Dei. To the contrary, Knoetze (2017:2) correctly pointed out that one of the important dealings of missiology as a discipline throughout the history of its existence is the interdependence that exists between the three legs of mission, missio Dei, missio ecclesiarum and missio hominum. Of these three, missio hominum 
functions as an instrument of missio Dei, as in the case of Mathew 14:13-21, Mark 6:30-44, John 6:1-14 and Luke 9:10-17, where Jesus Christ in his divine capacity as God is instructing and instrumenting his disciples to act out his mission. In this fashion, missio hominum depends on missio Dei to become active. This argument concurs with Smith (2002:18), who makes the argument that unlike missio Dei, in missio hominum God himself will not work in mysterious ways, but the people for whom God in the person of Jesus of Nazareth prescribed the agenda and issued instructions will do the work. Thus, whilst missio Dei involves God demonstrating his own mission by sending the Son and the Son sending the Spirit for the formation of his kingdom (Arthur 2013:1), missio hominum involves human demonstrations of missio Dei.

The call of this article is simply this: whilst God himself participated in the work of reconciling humanity to himself, human beings (Christians in particular) following missio hominum are here called to participate in the work of restoring society to public health amidst and after the COVID-19 pandemic. Thus, every human being, either through the endeavours of churches (missio ecclesiarum) or otherwise, is called to act out the mission of God (missio Dei).

\section{Socio-economic challenges}

The COVID-19 pandemic took its toll on a number of nations across the world, causing illnesses, claiming lives and causing serious economic despair. Unfortunately, South Africa is no exception to this list. During Alert Level 5, which began on midnight of 26 March and lasted until 30 April 2020, the virus was spreading at an alarming speed whilst the South African government was at low health system readiness (SA Government 2020). The restrictions that came with this level brought the entire country's economy to a near-freeze, and this resulted in multiple job losses and business closures. Francis et al. (2020) took the trouble to warn that it will probably take years or more before the damage caused by the COVID-19 pandemic can be accurately determined. However, Francis et al. (2020) further warned that: 'it is already clear that we will see a sharp decline in incomes, rising unemployment (increased by one percentage point, reaching $30.1 \%$ ), and widespread business closures'. One can imagine that it will take almost a decade before countries in general and South Africa in particular will develop the economic strength to climb out of the deep hole created by COVID-19. To be more specific, the United Nations Development Programme (UNDP) South Africa (2020:21) predicted that it will take at least five years to regain such economic strength.

Few facts about the impact of the COVID-19 pandemic should be dismissed or undermined. At the time of writing this article, South Africa alone had surpassed 1 million COVID-19 cases and had lost more than 37105 lives to COVID-19. These are not just mere numbers, but mothers, fathers, sons, daughters, uncles, brothers, sisters, friends and loved ones. According to Stats SA (2020) South Africa lost more than 600000 formal sector jobs during the COVID-19 lockdown(s). This means that at the time of the report there were at least 600000 people from the formal sector (excluding informal sector) who had lost their income. This means that more than 600000 households in South Africa lost income because of the COVID-19 pandemic, income that would otherwise have made life better for families possibly already troubled by poverty.

Socio-economically, COVID-19 not only brought countries to a near stop, taking jobs and ending lives prematurely, but also reversed years of progress and effort in eradicating poverty (UNDP South Africa 2020:14). Whilst scholars such as Pienaar (2017 :249) observed before COVID-19 that disease and poverty are ontologically entangled, unfortunately the impact of COVID-19 compared to other epidemics such as HIV has been much more dire practically, as it brought nations' economies to a halt for most of 2020. One is thus compelled by logic to conclude that the poor and marginalised people of South Africa most certainly will be as affected subsequent to COVID-19 as they were under the hard lockdowns.

Mainly for those living in informal settlements and rural areas, the lack of clean water and sanitation to comply with the water, sanitation and hygiene (WASH) recommendations suggested by WHO became a growing concern under COVID-19 (NBI 2020). This was also observed by Allan and Heese (2020), who noted that in South Africa the ability to social distance and maintain proper sanitation during the COVID-19 pandemic became a function of the well-off as opposed to those living in poverty.

At this juncture one can argue that it is true that the impact of COVID-19 is felt by some more severely than others. Sadly, one life or job loss is too many in a country with as many poor people as South Africa, where unemployment and inequality have been an issue for years. It is during times such as these, when the country is on its economic knees, when family spirits are broken beyond any possible repair, that the church of Christ is called to truly represent Christ and provide the poor and marginalised people of South Africa with what would seem to represent the much-needed bread of life (the COVID-19 vaccine).

\section{The challenge of corruption}

This section will demonstrate how South Africa's political and government system has been riddled with corruption and nepotism even during the time of distress. In addition, it will outline incidents where the South African government has been reckless with public funds that would otherwise benefit the procurement process. These are some of the indications of how reckless South African government officials have been even in the face of the pandemic. This will demonstrate reasons why the plight of the poor and the marginalised in South Africa cannot be left in the hands of government officials but rather should be entrusted to the collaborative efforts of both the church and government. In 
its simplicity corruption is a conduct that includes the private use of government funding and giving or accepting bribes and inappropriate gifts, defrauding the poor by diverting funds meant for the betterment of their lives. This section will show how the COVID-19 pandemic created an opportunity for corrupt politicians and government officials to serve their personal interests.

The COVID-19 outbreak in South Africa coincided with the continuing hearings of the alleged state capture commission, which exposed the seriousness of corruption and shocked all South Africans to their core. The evidence presented before Deputy Chief Justice Raymond Zondo synonymised the South African government with nothing less than a corrupt machine set on defrauding the poor and marginalised people of South Africa (February 2019). The commission's evidence has shown that politicians, government top officials and those in power will stop at nothing when it comes to enriching themselves whilst claiming to empower the poor (February 2019:1-16). Whilst the advent of the COVID-19 pandemic brought public life to a near stop, it unfortunately could not stop the fast moving train of corruption in South Africa. Instead, the advent of the pandemic seems to have encouraged the drivers of this train to accelerate even more. Relief packages came as the best opportunity for some politicians and government officials to dip their hands deep into the COVID-19 stimulus fund jar.

On 21 April 2020, President Cyril Ramaphosa announced an amount of R500 billion relief package aimed at supporting the vulnerable South Africans who found themselves in serious distress because of the pandemic. Ramaphosa said (Dludla 2020):

$[A]$ longside this unprecedented public health effort are the measures we are taking to protect livelihoods, to stave off hunger and destitution and to set our economy on a path of recovery. (n.p.)

In Mr Tito Mboweni's (South Africa's Minister of Finance) words: '[t]he (relief package) is one of the largest economic response packages in the developing world' (South African Parliament 2020).

On 02 September 2020, the late Auditor General of South Africa, Mr Kimi Makwetu, reported that the R500bn relief package had unfortunately 'landed in a weak control environment', pointing to the misuse and abuse of public resources meant for the poor in distress during the COVID-19 pandemic. In the words of the Special Investigating Unit (SIU) Progress Report (2021:12), 'it appears that ... the declaration of a national state of disaster meant that all procurement is automatically now conducted on an emergency basis'; hence corrupt individuals thought it was proper for them to circumvent the process and rely upon non-existent emergency situations (2021:49). Makwetu's report showed that the names of prison inmates and deceased people were used to claim benefits; public servants and many other categories of people who were not in distress defrauded the system by receiving COVID-19 benefits (Makwetu 2020).

\section{Food parcels corruption}

During the early days of the COVID-19 outbreak, the South African Social Security Agency (SASSA) used a portion of its budget to buy food parcels that would be distributed to those in need (Makwetu 2020). Shortly after this was done, reports of food parcel corruption surfaced. Those entrusted with the distribution of the food parcels had decided either to sell them or give them to their relatives and their close comrades (Moche 2020).

In Gauteng on 23 April 2020, it was reported that food parcels were delivered to a local crèche and disappeared that same night. A Democratic Alliance member, Refiloe Nt'sekhe, described the aftermath, saying: 'the community had already queued up waiting for food parcels. As you can imagine people are hungry this time' (Breakfast 2020). After a similar incident happened in Kimberly, one of the residents was quoted saying (Mothata 2020):

[I] need that food parcel because I have a child. I have a family at home. I have a big responsibility. They can't even give us jobs. If they give us jobs, then we won't need these food parcels. (n.p.)

One Ms Nongcobo Shangase from New Germany in Durban reported that whilst they were suffering badly during the hard lockdown with no food, ward councillors gave food parcels to their friends using their identification numbers. She said (Corruption Watch 2020):

$[I] \mathrm{t}^{\prime} \mathrm{s}$ such a disgrace and just yesterday they gave a few people just $1 \mathrm{~kg}$ mielie meal; $1 \mathrm{~kg}$ sugar; $1 \mathrm{~kg}$ instant porridge; 100 teabag packet of Trinco; two cans of chakalaka baked beans; two packets of spaghetti; $500 \mathrm{~g}$ of macaroni; two $500 \mathrm{~mL}$ of cooking oil; $750 \mathrm{~g}$ of peanut butter and $400 \mathrm{~g}$ of biscuits. Most of the people who arrived for the parcels were chased away. (n.p.)

These stories seem to match up with that of Mr Victor Khumalo from Ekurhuleni in Gauteng, who reported that two councillors who were actively involved in the distribution of food parcels were using their comrades to handle food matters. He said (Corruption Watch 2020):

$[W]$ hat gives us a headache is that they come with food to the community and decide who should get it and who should not. Obviously if they don't like you, or you're not on their side, you won't get anything. (n.p.)

\section{Personal protective equipment corruption}

The SIU Progress Report (2021) found that political pressure played a role in influencing the irregular procurement of PPE. According to Masondo (2020) in August the SIU had to freeze bank accounts belonging to top Gauteng government officials such as the Gauteng Health Department's former chief financial officer (CFO), Kabelo Lehloenya, a member of the mayoral committee in the City of Johannesburg, and that of Noloyiso Masuku, who is the wife of the recently dismissed Gauteng health Member of the Executive Council (MEC) Bandile Masuku (Maromo 2020). According to Ndaba (2020), 
these officials were involved in allegations of irregular issuing of PPE tenders to the tune of R1.9bn. In Business Tech on 09 August 2020, it was indicated that Gauteng Premier David Makhura had discovered that goods and services to the tune of R239 million had been received by the health department from companies that were not tax compliant and had unverified bank accounts, R82m worth of goods had been procured from unregistered companies, R12m worth of goods had been delivered to the department without issuing of purchase orders, $\mathrm{R} 5 \mathrm{~m}$ had been paid for the delivery of PPE to companies that did not secure contracts with the government and $\mathrm{R} 4.5 \mathrm{~m}$ had been paid to companies that did not supply any goods or services to the department. The SIU Progress Report (2021:37) highlighted that influential people in government, along with their families and friends, benefitted hugely from PPE procurement. This is substantiated by the incident that reportedly took place on 03 August 2020, whereby the Gauteng Department of Health made a payment of R38 758155 into a corrupt supplier's account, which in turn paid money to other two entities, who in turn paid money to at least 36 other entities (2021:21).

Reported corruption related to the COVID-19 relief fund was not limited to food parcels and PPE but extended to the social relief grants meant for the unemployed and struggling informal businesses, the farmers' relief fund meant for smallscale farmers in distress, the tourism relief fund and many other areas.

Unfortunately, the recklessness on the part of South African government officials in handling public funds was not limited to the corruption witnessed during the height of the COVID-19 pandemic but included wasteful expenditure projects in the face of the crisis. During the early months of 2020, the government was supposed to be leading advanced preparations for a massive vaccine procurement for its people, like other big countries across the world. Instead, on 28 October 2020, Minister of Finance Mr Tito Mboweni announced during his medium-term budget speech that a state-owned enterprise (SOE), South African Airways (SAA), would receive a bail-out of R16.4bn (Vecchiatto 2020). This came just after the same company (SAA) received a bail-out of about R1605bn in February of 2020 (Hill-Lewis 2020). Another controversial SOE that had to be bailed out along with SAA was the South African electricity public utility, Eskom. This company had its annual budget increased to R112bn from the 2020/21 financial year to 2023. According to the SIU Progress Report (2021:47), the Eastern Cape Department of Health was found to have performed an irregular procurement process in awarding a tender with a contract value of R10.1m to the company Fabkomp as the sole service provider for 100 motorbikes (R101 000 per motorbike) during the hard lockdowns in June of 2020.

Corruption that took place during the COVID-19 pandemic, with funds reprioritised for the poor people of South Africa in distress, is evidence enough that the plight of the poor cannot be left in the hands of politicians and government officials. However, this highlights the important role that South African churches are expected to play in preserving lives that would otherwise be lost, should the vaccine procurement project be left in the hands of politicians and government officials alone.

\section{Challenge of procuring the COVID-19 vaccine}

President Cyril Ramaphosa in his speech of 11 January 2021 indicated that the only way for South Africa to fully defeat the COVID-19 pandemic is if the country undertakes a massive programme of vaccination within a short period of time. Once this is done, South Africa will have achieved herd or population immunity against COVID-19; hence he called the COVID-19 vaccine a 'game changer'. He further indicated that this would be the largest and most complex health project in the history of South Africa (Ramaphosa 2021).

According to AmaShabalala (2021) South Africa's health minister, Zweli Mkhize, briefed the Parliamentary Portfolio Committee on Health on the country's COVID-19 vaccine programme on 07 January 2020, indicating that South Africa would receive its first million doses of COVID-19 vaccine during that same month (January 2021). This came after the health department reached an agreement with an Indian biotechnology and pharmaceuticals company, Serum Institute of India, that South Africa would procure the first batch of COVID-19 vaccine doses for its front-line workers. In his own words Minister Zweli Mkhize said:

[T] oday we announce that South Africa will be receiving the first one million doses of the Oxford/AstraZeneca vaccine in January and another 500000 in February from the Serum Institute of India. (n.p.)

When the South African government finally received the Oxford/AstraZeneca vaccine on 01 February 2021, societal emotions ran high as this was one of the first signs that the COVID-19 pandemic would be brought under control. Unfortunately, such hopes were shattered when the trial study involving at least 2000 people indicated that this vaccine did not offer the much-needed protection against mild and moderate disease caused by the 501Y.V2 viral variant dominant in South Africa (Pheby 2021). The problem presented by this discovery was that any possible vaccine with adequate efficacy against 501Y.V2 would have to be studied and produced in South Africa, a challenge that will surely cost South Africa millions of rand to overcome, notwithstanding its financial difficulties. As if this setback was not enough, it was discovered that even though ordinary vaccines have 6 months before expiry, the Oxford/AstraZeneca vaccine was dated to expire in April of 2021, resulting in its roll-out being put on hold (Mwai 2021).

The plan is that once South Africa receives COVID-19 vaccine doses, it will first cover $10 \%$ of the total population. The 
government strategy consists of three phases, as indicated by President Cyril Ramaphosa (2021):

- In Phase 1, about 1.2 million front-line health workers will be prioritised for the vaccine.

- In Phase 2, all essential workers (municipal workers, frontline personnel, teachers and the police) will be prioritised.

- In Phase 3, the remaining adult population of about 22.5 million people will be vaccinated.

Looking at this plan, the possibility that the poor and marginalised of South Africa will probably be reached last is not remote. And the logical consequence is that they (the poor and marginalised) will remain under a high risk of being infected and dying whilst waiting for the COVID-19 vaccine to reach them. To prevent this disaster from happening, it is important for all societal stakeholders to play their part in preserving lives by any means possible, and this includes churches. If churches are to remain relevant in South Africa, it is important that they confront the challenge that is about to face the poor and the marginalised. One cannot rule out the possibility that the second phase of vaccination will be around the second half of 2021, and whilst it is concerning that some people will lose their lives in the interim, at the same time this will give churches ample time to approach and seek funds from willing donors. South African churches can work together in procuring and distributing vaccines to the 'backline people' (the poor and marginalised). This way the church would have performed its missiological mandate of looking after the poor and marginalised; in doing this the churches would have provided the best bread, similar to what Jesus gave to 5000 men (excluding women and children).

\section{Missio hominum as compassion to the poor}

The greater mission of the church can only be angled around what Jesus did and said whilst on earth. The one example to illustrate this point is his feeding of 5000 men (excluding women and children) with just five loaves and two fish. Of all the miracles performed by Jesus on earth, this is the only miracle story that occurs within all four gospels: Mathew 14:13-21, Mark 6:30-44, John 6:1-14 and Luke 9:10-17. It is no coincidence that this happened shortly after Jesus had sent his disciple on a mission to heal the sick (Luke 9:6).

This episode began with Jesus attempting to withdraw to an isolated place but later realising that he was rather in high demand as the great multitude longed to see his signs (Mk $6: 34 ;$ Jn 6:2). He then started preaching about the kingdom of God, after which his disciples indicated that he should rather send the crowd home as they could not feed all of them. However, Jesus instructed that they be gathered in groups, at which point he gave thanks, broke the bread and fish, and directed them to feed all 5000 men (beside women and children). After the feast there were 12 baskets of leftovers.
What is clear from this story is that by feeding 5000 hungry men, Jesus sought to train his disciples to demonstrate extraordinary compassion and be true leaders when the need arises. He sought to demonstrate to them that if singlehandedly he could show enough compassion for 5000 men together with their women and children, collectively they (disciples) could surely do much more. Out of true compassion Jesus did not seek to feed people snakes or make them drink petrol (Kgatle 2017:1-3). Instead, Jesus saw their hunger and demonstrated his compassion by turning what little he had (five loaves and two fish) into abundance. Surely South African churches can follow that example by working collectively towards providing the poor and marginalised people of South Africa with an abundance of vaccines at a time when the South African government is rather more concerned with the 'frontline workers'. In the context of the COVID-19 pandemic and the challenges of finding vaccines, churches are missionally obliged to identify with and demonstrate compassion to all poor and marginalised South Africans. Van der Merwe (2020) is spot on in calling for the churches of South Africa to become an agent of change amidst the COVID-19 pandemic by invoking the words of the Belhar Confession:

We believe that God has revealed himself as the one who wishes to bring about justice and true peace among men; that in a world full of injustice and enmity he is in a special way the God of the destitute, the poor and the wronged and that he calls his church to follow him in this; that he brings justice to the oppressed and gives bread to the hungry ... (p. 2)

If South African churches could arrange the installation of automated teller machines (ATMs) and speed point machines in their buildings to encourage congregants to give easily (Masenya \& Masenya 2018:634), surely arranging for a central fundraising account to be used to assist in the procurement of COVID-19 vaccines cannot be a difficult task to achieve. This will surely be symbolic of the best kind of bread and fish to the poor and marginalised people of South Africa during and beyond the COVID-19 crisis. As such, the pandemic will have provided the churches of South Africa with an occasion for reaching out to the poor and marginalised people of South Africa more than ever before.

\section{Missio hominum in the light of fundraising for the poor}

The idea that South African churches, even though under stringent funds because of extreme loss of weekly offerings, should at least work side by side with government to assist the poor and marginalised people during the pandemic is not remote to some church leaders, such as Pastor Paseka Mboro Motsoeneng of Incredible Happenings Ministry in Katlehong, who was quoted on ENCA (2020) news saying:

[C]hurches must turn around and say how do we make our churches profitable? How do we have other ways ... other wings that will support the church financially, that we empower people and people and give back? Not just take from people and misuse that money. (n.p.) 
Effectively Pastor Mboro is merely asking church leaders to be more creative and proactive in working towards making the burden of the COVID-19 pandemic bearable to church members. Similarly, this article challenges church leaders and theological scholars to be creative and come up with ideas to assist government with the current task of assisting the survival of the poor and marginalised people. In this regard, the method of fundraising is outlined as one of the multiple mechanisms that churches can use in efforts to assist in bearing the cost imposed by the pandemic. Similarly Van der Merwe (2020) acknowledged the call made by the South African Council of Churches (SACC) after it recognised that the only way for South Africa to survive the pandemic was collaboration between churches and government (Van der Merwe 2020:5-6). He concluded by quoting Pope Francis' words as emphasised by Pillay (2017): 'our faith in Jesus impels us to live charity through concrete gestures capable of affecting our way of life, our relationships and the world around us' (Pillay 2017:11).

For a long period of time fundraising has been a method embraced by Christians to increase giving for different purposes and reasons. In fact, fundraising has always been embraced by biblical heroes such as Hezekiah (2 Chr 31), David (1 Chr 29:1-20), Moses (Ex 25, 35 and 36), Nehemiah (Neh 1 and 2), Apostle Paul (1 Cor 16:1-4) and Jesus Christ himself (Mk 6:8; Lk 8:1-3). Of particular interest for this article are the accounts of Apostle Paul and Jesus Christ pertaining to their embracement of fundraising.

\section{Jesus Christ and fundraising}

As early as Matthew 10 we learn of how Jesus sent his disciples on a mission, instructing them to take nothing with them for that journey. Instead he told them that whatever town or village they entered, someone worthy would be there to lend them the support they would need. In fact, Mark 6:8 puts his words bluntly: 'Take nothing for the journey except a staff - no bread, no bag, and no money in your belts'. Furthermore, in Luke 8:1-3 we learn how those who followed Jesus Christ (the likes of Mary Magdalene, Joanna, Susanna and many others) provided for Jesus and his disciples out of their own resources.

\section{Apostle Paul and fundraising}

The New Testament is full of stories of how Apostle Paul approached fundraising as a form of ministry. He used fundraising as a special way of letting others know about Christ's vision and even inviting them to be part of Christ's mission. Adam (2020:275) correctly suggested that Paul's fundraising always centred on gratitude, generosity and mission. Further, he highlighted the fact that in the history of the church there was a time (47-49 AD/CE) when the Jerusalem church was faced with challenges of socioeconomic ostracism, persecution, double taxation, widowhood and extreme famine. It was in these circumstances that a meeting in the autumn of $51 \mathrm{CE}$ was held at which Apostle Paul was tasked with the project of raising funds for the Jewish saints. Because the church did not have enough in its pockets to take care of itself, the widows and those severely affected by extreme famine, it then had to rely on external entities to assist it financially so that it could continue to live up to its missional call. Later, in Philippians 4:10-20 Apostle Paul praised the church in Philippi for their contribution to his mission course when he was in desperate need whilst doing mission. Further, it is for these exact reasons that in 1 Timothy 6:17-19 the apostle felt the need to ask Timothy to command wealthy Christians to be generous givers and share their wealth with the have-nots. The common trend here is that Apostle Paul, the Philippians and Timothy represent the church as it was called to bear the plight of the poor and marginalised.

During this time of distress and desperate need in South Africa, when many lives are at stake because of COVID-19, churches are here called to do exactly what the church has always done in times of desperate need: churches are called to make use of the tools that are available in the fight against COVID-19 (collective fundraising). This article cries a missional call to all churches in South Africa to come together with the vision of preserving lives in the face of the monstrous pandemic. It calls on all churches of South Africa to truly do as the early church did and raise funds for the poor and marginalised in time of distress. The simple call to South African churches is to work together towards developing a fundraising system that will focus on soliciting enough funds for the COVID-19 vaccine, separate from but at the same time in partnership with the South African government, for the poor and marginalised people of South Africa. As Jesus promised to his disciples as they journeyed into a new mission, there will surely be millions of worthy men and women in South Africa and abroad who will lend financial support towards the procurement of a special COVID-19 vaccine for the poor and marginalised of South Africa. This call coincides with Kgatle (2020), who argued that:

$[T]$ he poor cannot be isolated during online church. If universities are distributing data to the poor students during lockdown, nothing stops churches to do the same to their poorest members to minister the gospel to them. (p. 5)

This is the least that churches can collectively do in restoring public health. Thus, armed with this ammunition, South African churches are called to not allow the poor and the marginalised people to bear the burden imposed by COVID-19.

\section{Donors for vaccine procurement}

One of the exemplary companies that contributed huge amounts of money towards the procurement of COVID-19 vaccine was Africa's leading cellular network, MTN (Opensignal 2020). In his speech of 01 February 2021 President Cyril Ramaphosa applauded the MTN group for its donation of US $\$ 25 \mathrm{~m}$ for the procurement of vaccines for the African continent, which amounted to 7 million doses of vaccine (Shange 2021). 
Nicolson (2021) showed that medical aid schemes in South Africa are also geared up towards financing the procurement of COVID-19 vaccines for both their members and high-risk non-members alike. Companies such as Discovery and Momentum indicated that they were having funding discussions with the South African government in this regard. The Discovery chief executive officer, Dr Ryan Noach, was quoted saying: 'we are delighted to be collaborating with the national department of health and working in solidarity to ensure adequate funding of vaccines for all South Africans' (Nicolson 2021).

This shows the importance of different sectors coming together and working towards providing equitable access to vaccines. Further, this shows that there are many companies out there (inside or outside South Africa) that are willing to contribute towards the restoration of public health. However, with the benefit of hindsight on the corruption that took place under the hard lockdowns in 2020, willing donors will certainly be concerned about the integrity of those who will be on the receiving end of their funds. No donor would ever wish to throw their money into a deep black hole (corruption). Whilst the corruption that took place under the hard lockdowns cannot be promoted or tolerated, it is in such weakness by government that the churches of South Africa are called to raise and reclaim their name and relevance. Beukes (2020:2) is correct in arguing that a crisis should not be viewed in a negative light but should rather be seen for its potential and the opportunities it presents. Thus, accordingly South African churches must use this opportunity to reinvent and reclaim their relevance.

Another example in this regard is the Solidarity Fund that was established by President Cyril Ramaphosa as one of the early interventions to cushion the impact of COVID-19. This fund was chaired by the South African businesswoman Ms Gloria Serobe, assisted by deputy chairperson Dr Adrian Enthoven. A team of reputable persons from accounting firms, government and other financial institutions were also appointed to administer the funds. In his announcement President Ramaphosa indicated that the South African government had contributed seed capital of R150m to the fund (Mthethwa 2020). As well, contributing to this fund were businesses and individuals alike; according to the fund webpage its multimillion donors included the likes of Mary Oppenheimer and daughters, Lottery South Africa and the Elma South Africa foundation (Solidarity Fund 2021).

\section{Conclusion}

This article discussed the role that churches in South Africa can and ought to play in assisting efforts to procure vaccines for the poor in response to socio-economic and vaccine challenges during and after the COVID-19 pandemic in South Africa. It juxtaposed the provision of vaccines with how Jesus fed 5000 men (excluding women and children) as stated in Matthew 14:13-12, Mark 6:30-44, John 6:1-14 and Luke 9:10-17. It strongly argued that corruption as witnessed by many in South Africa during the height of COVID-19 in 2020/2021 around the procurement of PPE, distribution of food parcels and subversion of relief packages should be taken by South African churches as a strong message that they can no longer leave public health or its restoration in the hands of South African government officials and politicians but should work side by side with government to prioritise the needs of poor and marginalised people. The article made use of missio hominum shadowed by missio Dei as its preferred missiological theory in calling for South African churches to collectively demonstrate true compassion towards the socio-economic challenges that South Africa is facing because of the COVID-19 pandemic and establish a nationwide church fundraising effort towards procuring vaccines for the poor and marginalised people of South Africa.

\section{Acknowledgements Competing interests}

The author declares that he has no financial or personal relationships that may have inappropriately influenced him in writing this article.

\section{Author's contributions}

J.S.T. is the sole author of this research article.

\section{Ethical considerations}

This article followed all ethical standards for research without direct contact with human or animal subjects.

\section{Funding information}

This research received no specific grant from any funding agency in the public, commercial or not-for-profit sectors.

\section{Data availability}

Data sharing is not applicable to this article as no new data were created or analysed in this study.

\section{Disclaimer}

The views and opinions expressed in this article are those of the author and do not necessarily reflect the official policy or position of any affiliated agency of the author.

\section{References}

Adam, I.S., 2020, 'Apostle Paul's fundraising economic theory of savings and social change', E-Journal of Religious and Theological Studies 6(6). https://doi. org/10.38159/erats.2020091

Allan, K. \& Heese, K., 2020, 'COVID-19 affects the poor more than others, and even more so in SA', Business Day, viewed 19 January 2021, from https://www. businesslive.co.za/bd/opinion/2020-04-10-COVID-19-affects-the-poor-morethan-others-and-even-more-so-in-sa/.

Amashabalala, M., 2021, SA to get first million doses of COVID-19 vaccine this month Zweli Mkhize, viewed 18 January 2021, from https://www.timeslive.co.za/ politics/2021-01-07-sa-to-get-first-million-doses-of-COVID-19-this-month-zwelimkhize/.

Arthur, E., 2009, Missio Dei: The mission of God, viewed 18 March 2021, from https:// www.kouya.net/upload/missionofgod.pdf.

Arthur, E., 2013, Missio Dei and the Mission of the Church, viewed 11 April 2021, from https://static1.squarespace.com/static/56dee43ee321400514f98522/t/575c31a $8 \mathrm{e} 32140042 \mathrm{bb} 2 \mathrm{~b} 7 \mathrm{bb} / 1465659816891 / 3+$ MISS+301+Mag+3.pdf. 
Beukes, J.W., 2020, 'To be or not to be? A missional and practical theological perspective on being church without walls amidst coronavirus disease 2019: A challenge or an opportunity?', HTS Teologiese Studies/Theological Studies 76(1) a6115. https://doi.org/10.4102/hts.v76i1.6115

Bosch, D.J., 1991, Transforming mission: Paradigm shifts in theology of mission, vol. 16, no. 1, Orbis Books, New York, NY.

Bosch, D.J., 2011, Transforming mission: Paradigm shifts in theology of mission, Maryknoll, Orbis Books, New York, NY.

Breakfast, S., 2020, Lesufi urged to investigate disappearing food parcels, viewed 13 May 2021, from https://www.thesouthafrican.com/news/lesufi-urged-toinvestigate-disappearing-food-parcels/.

Corrie, J., 2016, 'Creative tensions in mission Bosch 25 years on', Missionalia 44(2), 192-204. https://doi.org/10.7832/44-2-147

Corruption Watch, 2020, Food parcel distribution falls prey to corruption, viewed 10 May 2021, from https://www.corruptionwatch.org.za/corruption-steals-frompeople/.

Dludla, S., 2020, Ramaphosa announces R500bn support package as COVID-19 hits SA economy, viewed 16 January 2021, from https://www.iol.co.za/business-report/ economy/ramaphosa-announces-r500bn-support-package-as-COVID-19-hits-saeconomy-47002575.

ENCA, 2020, WATCH: Churches want compensation for lost offerings, eNCA, viewed 10 May 2021, from https://www.enca.com/news/watch-churches-wantcompensation-lost-offerings.

February, J., 2019, State capture: An entirely new type of corruption, Institute for Security Studies (ISS) Report (25), pp. 1-16, viewed 25 April 2021, from https:// issafrica.s3.amazonaws.com/site/uploads/sar-25.pdf.

Flett, J.G., 2014, A theology of missio Dei, viewed 11 April 2021, from https://core. ac.uk/download/pdf/80685405.pdf.

Francis, D., Valodia, I. \& Ramburuth-Hurt, K., 2020, COVID-19: The full economic impact will only be known later, viewed 16 January 2021, from https://www.wits. ac.za/covid19/covid19-news/latest/COVID-19-the-full-economic-impact-willac.za/covid19/covid19-n
only-be-known-later.html.

Hill-Lewis, G., 2020, Cut SAA bailout to fight coronavirus, viewed 16 January 2021 from https://www.news24.com/fin24/opinion/opinion-cut-saa-bailout-to-fightcoronavirus-20200320.

Kgatle, M.S., 2017, 'The unusual practices within some Neo-Pentecostal churches in South Africa: Reflections and recommendations', HTS Teologiese Studies Theological Studies 73(3), a4656. https://doi.org/10.4102/hts.v73i3.465

Kgatle, M.S., 2018, 'Social media and religion: Missiological perspective on the link between Facebook and the emergence of prophetic churches in southern Africa', Verbum et Ecclesia 39(1), a1848. https://doi.org/10.4102/ve.v39i1.1848

Kgatle, M.S., 2020, 'Religious live-streaming in response to coronavirus disease 2019 pandemic and the subsequent lockdown in South Africa', Verbum et Ecclesia 41(1), a2120. https://doi.org/10.4102/ve.v41i1.2120

Khan, J.S. \& Mclntosh, K., 2005, 'History and recent advances in coronavirus discovery', The Pediatric Infectious Disease Journal 24(11), 223-227. https://doi. org/10.1097/01.inf.0000188166.17324.60

Knoetze, J.J., 2017, 'A long walk to obedience: Missiology and mission under scrutiny (1910-2010)', In die Skriflig 51(2), a2192. https://doi.org/10.4102/ids. v51i2.2192

Makwetu, K., 2020, Auditor-general says the multi-billion rand COVID-19 relief package landed in an environment with many control weaknesses, viewed 08 January 2021, from https://www.agsa.co.za/Portals/0/Reports/Special\%20 Reports/COVID-19\%20Special\%20report/2020\%20COVID-19\%20Media\%20 Release\%20FINALISED.pdf.

Masenya, M. \& Masenya, M., 2018, 'Church breakaways as a prototype of commercialisation and commodifi cation of religion in the Pentecostal Church Movement in South Africa: Considering curricula off erings for pastors', Stellenbosch Theological Journal 4(2). https://doi.org/10.17570/stj.2018.v4n2.a29

Maromo, J., 2020, Bandile Masuku fired over Covid-19 PPE tender irregularities, 11 November 2020, https://www.iol.co.za/news/politics/bandile-masuku-firedover-covid-19-ppe-tender-irregularities-d230bfa 7-3052-562f-b10c$63 \mathrm{a} 86 \mathrm{c0} 031 \mathrm{e} 9$

Masondo, S., 2020, COVID-19 corruption: Accounts in PPE scandal frozen, viewed 13 January 2021, from https://www.timeslive.co.za/sunday-times/news/202008-16-COVID-19-corruption-accounts-in-ppe-scandal-frozen/.

Moche, T., 2020, TIMELINE: COVID-19 food parcels, PPE corruption timeline, viewed 08 January 2021, from https://www.sabcnews.com/sabcnews/timeline-COVID 19-food-parcels-ppe-corruption-timeline/.

Mothata, W., 2020, DA calls on Lesufi to investigate food parcel theft, viewed 18 January 2021, from https://www.sabcnews.com/sabcnews/da-calls-on-lesufito-investigate-food-parcel-theft/
Mthethwa, M., 2021, Ramaphosa sets up solidarity fund to cushion impact of COVID-19, viewed 18 January 2021, from https://www.sabcnews.com/sabcnews/ ramaphosa-sets-up-solidarity-fund-to-cushion-impact-of-COVID-19/.

Mwai, P., 2021, Coronavirus: When will South Africa start vaccinating?, viewed 13 February 2021, from https://www.bbc.com/news/world-africa-55675806.

NBI, 2020, Water quality, sanitation and hygiene in light of COVID-19 - National Business Initiative, viewed 10 May 2021, from https://www.nbi.org.za/covid19/ water-quality-sanitation-and-hygiene-in-light-of-covid-19/.

Ndaba, B., 2020, 2020 through the political lense - PPE corruption, COVID-19 scandals and high profile court battles, viewed 12 January 2021, from https://www.iol. co.za/news/politics/2020-through-the-political-lense-ppe-corruption-COVID-19scandals-and-high-profile-court-battles-67477d8a-45e9-4124-88a88def6e025451.

Nicolson, G., 2021, Medical aid schemes back collaborative national effort on vaccine funding, viewed 08 January 2021, from https://www.dailymaverick.co.za/ article/2021-01-06-medical-aid-schemes-back-collaborative-national-effort-onvaccine-funding/.

Opensignal, 2020, South Africa, March 2020, mobile network experience, viewed 13 May 2021 from https://www.opensignal.com/reports/2020/03/southafrica/ mobile-network-experience.

Pheby, J., 2021, AstraZeneca vaccine less effective against S. African strain: Study, viewed 09 February 2021, from https://ph.news.yahoo.com/astrazeneca-covidjab-less-effective-112727218.html.

Pienaar, K., 2017, 'Rethinking the poverty-disease Nexus: The case of HIV/AIDS in South Africa', Journal of Medical Humanities 38(1), 249-266. https://doi. org/10.1007/s10912-015-9369-x

Pillay, J., 2017, 'The church as a transformation and change agent', HTS Teologiese Studies / Theological Studies 73(3), 1-12. https://doi.org/10.4102/hts.v73i3.4352

Ramaphosa, 2021, Statement by President Cyril Ramaphosa on progress in the national effort to contain the COVID-19 pandemic, viewed 12 January 2021, from http://www.thepresidency.gov.za/speeches/statement-president-cyrilramaphosa-progress-national-effort-contain-COVID-19-pandemic\%2C-11january-2021.

SA Government, 2020, About alert system, South African Government, viewed 16 February 2021, from https://www.gov.za/covid-19/about/about-alert-system.

Shange, N., 2021, Nobody will be forced to take COVID-19 vaccine, says Cyril Ramaphosa, viewed 03 February 2021, from https://www.timeslive.co.za/ politics/2021-02-01-nobody-will-be-forced-to-take-COVID-19-vaccine-says-cyrilramaphosa/.

Smith, N., 2002, 'From Missio Dei to Missio Hominum En route in Christian mission and missiology', Missionalia 30(1), 4-2, viewed 08 January 2021, from https:// journals.co.za/doi/10.10520/AJA02569507_1222.

Soares, D.R., Lotter, G. \& Van der Merwe, S.J., 2017, 'The missio Dei as context for a ministry to refugees', In die Skriflig 51(1), 1-7. https://doi.org/10.4102/ids.v51i1.2101

Solidarity Fund, n.d., News \& Updates, viewed 11 March 2021, from https:// solidarityfund.co.za/news-updates/.

South African Parliament, 2020, The R500 billion stimulus package is one of the largest economic response packages in the developing world - Tito Mboweni, viewed 19 January 2021, from https://www.parliament.gov.za/news/r500-billion-stimuluspackage-one-largest-economic-response-packages-developing-world-titombowen

Special Investigating Unit (SIU) Progress Report, 2021, COVID-19 PPE procurement report, viewed 06 February 2021, from https://www.siu.org.za/wp-content/ uploads/2021/02/R23 of_2020_Final_report_on_matters_finalised_for_public release 05022021.pdf.

Stats SA, 2020, SA loses more than 600k formal sector jobs during COVID-19 lockdown viewed 16 January 2021, from http://www.statssa.gov.za/? $p=13690$.

UNDP South Africa, COVID-19 in South Africa: Socioeconomic impact assessment United Nations in South Africa, viewed 16 January 2021, from https://reliefweb. int/sites/reliefweb.int/files/resources/UNDP\%20-\%20Socioeconomic $\% 20$ Impact $\% 20$ Assessment $\% 20$ Socioeconomic $\% 20$ Impact $\% 20$ Assessment $\% 20$ 2020_FINAL.pdf.

Van Aarde, T.A., 2017, 'The relation of God's mission and the mission of the church in Ephesians', Missionalia 44(3), 284-300. https://doi.org/10.7832/44-3-117

Van der Merwe, J.M., 2020, 'Poverty and the COVID-19 pandemic: A challenge to the church', HTS Teologiese Studies/Theological Studies 76(1), a6221. https://doi. org/10.4102/hts.v76i1.6221

Vecchiatto, P., 2020, South Africa bails out airline after investor search fails, viewed 18 January 2021, from https://www.bloomberg.com/news/articles/2020-10-28/ south-africa-bails-out-insolvent-state-airline-with-641-million.

Verkuyl, J., 1981, Inleiding in de nieuwere zendingswetenschap, 2e druk, Kok, Kampen.

Verster, P., 1997, 'All-inclusive mission - A discussion of Transforming mission (1991) by D.J. Bosch', In die Skriflig 31(3), 251-266. https://doi.org/10.4102/ids.v31i3.1611 